\title{
Measuring essential quality parameters for organized food retailers - A survey in Rajkot city
}

\author{
Vishva B. Kothadiya \\ (MBA, School of Management, RK University, India)
}

\begin{abstract}
A study was conducted to identify essential quality parameters for organized food retailers on the bases of customer opinion about different area of service quality. For this factor analysis was used to determine responsible factors for measuring the satisfaction level among organized food retail customers. Study results that quality parameters such as more product variety, attractive discounts, branded product in food and grocery segment, neatness and hygiene, freshness of food were positively affected to customers in selection of organized food retail over unorganized food retail. Which indicate that organized food retails should concentrate on these parameters in delivering services to their customers. Study also identifies areas in which organized food retailers are lacking in services i.e. After sales, credit facility, consistency in services and personal attendance to customers. So they should concentrate on weak area of performance in services and try to improve service quality in these areas.
\end{abstract}

Keywords: customer satisfaction, factor analysis, organized food retailing, quality parameters, super markets.

\section{Introduction}

In the present Indian scenario quality of product and services has become essential feature to achieve and hold position in the market place. Quality of services is an indispensable competitive strategy to retain customers. Service providers are constantly seeking unique ways to differentiate their offering. The willingness and ability of managers in service organizations to respond to changes in service economy will determine whether their organizations survive and prosper. Increasing customer's expectations will gain considerable importance for higher services quality expectation from service providers. To identify the quality parameters for your target group customer is very essential for any service providers. Despite the fact that food and grocery contribute to major portion of sales done by organized retailers it a most difficult category to manage from retailer's point of view. According to one study challenges face by organized food retailers is perishability of food, wastage of products, dealing with number of small suppliers, inflated food prices etc. Apart from these maintaining consistency in services along with changing expectations of customers is require a depth research related to identifying essential quality parameters from customers point of view.

The finding of the research may also add new knowledge to the subject of service quality measurement as well as to organized food and grocery retail service providers. Further the management of organized food retail stores can use these finding to retain existing customers and attract new one.

\subsection{Organized Retailing in India}

Indian retail is dominated by a large number of small retailers consisting of the local kirana stores, general stores, apparel shops, chemists, footwear shops, and pavement vendors etc. which together make up the so-called unorganized retail segment. But Indian retail scenario is definitely headed for a major e years to come. The next few years are likely to witness rapid growth in the organized retailing sector with several leading international players establishing their presence in India by adjusting their formats to suit local tastes and buying behavior.

Responsible factor for growth of organized retail sector are higher disposable income, increase in number of working women, growing proportion of youth in overall population, changing life style of customers and changing food habits and many more. Retail is the most growing sector in Indian. Share of retail industry in current GDP stands for 30\%. Total retail market in India is of $300 \mathrm{bn} \$$ out of which organized retail contribute $6.5 \%$. Average growth of organized retail in India is $17.39 \%$ yearly. Major categories in organized retails are food and grocery (12.5\%), Apparel and clothing (35\%), Consumer Electronics (9.2) and other categories. (India Retail Report 2011, published by Images Group)

\subsection{Organized food retailing in India and Gujarat}

Organized retail includes many categories out of which food retail is major category. Food retail is most attractive category responsible for highest footfall of customers in organized retail malls. Retail categories in organized market contributing apparel and clothing (35\%), food and grocery (12.5\%), foot wear (9.3\%), consumer electronics $(9.2 \%)$ were as other categories such as personal care and fitness, accessories and eye care 
are yet to touch single digit contribution. (Source, Indian retail report 2011) In the area of food retail concentration of the researchers, academicians and retail managers were diverted and expanded into scrutinizing the food retail business.

But in competitive environment specifically where people having habit to purchase food and grocery form near by unorganized retailers, it is very essential for organized food retailers to know essential quality parameters evaluated by customers. This study focus on measuring quality parameters for organized food retails. Providing high quality services to customers create an opportunity for retailers to build a positive image in mind of customers. High service quality results in customer satisfaction and loyalty, greater willingness to recommend to others, reduction in customer complaints and improved customer retention rates (Bitner, 1990). There are many model of service quality which measures quality of services provided by service provider. But there is a lack of literature on essential quality parameters in organized food retail sector. The purpose of this research paper is to identify important quality parameters on the basis of customer's opinion on important criteria they keep in mind at the time of purchase of food from organized retailers. On the basis of customers review we can identify quality parameters require to maintain by organized food retailers.

\section{Literature Review}

Indian retail is dominated by a large number of small retailers consisting of the local kirana stores, general stores, apparel shops, chemists, footwear shops _ and pavement vendors etc. which together make up the so-called unorganized retail segment. But Indian retail scenario is definitely headed for a major transformation in the years to come. The next few years are likely to witness rapid growth in the organized retailing sector with several leading international players establishing their presence in India by adjusting their formats to suit local tastes and buying behavior. Indian retail is divided in to organized and unorganized sector. Portion of organized retail is very less but there is a huge opportunity for this sector to grow.

Organized retail covers only $6.5 \%$ (19.5 billion $€)$ of the Indian market. But it is expected to increase in next few years. It is growing at $17.39 \%$ year on year. Organized retail includes many categories out of which food retail is major category. Retail categories in organized market contributing apparel and clothing (35\%), food and grocery $(12.5 \%)$, foot wear $(9.3 \%)$, consumer electronics $(9.2 \%)$ were as other categories such as personal care and fitness, accessories and eye care are yet to touch single digit contribution. Goswami Paromita, (2009) in his study try to understand that is it possible for Indian customer to move from traditional kirana stores to large organized retail stores for groceries requirement. Major findings in study indicate that customer's patronage to grocery store is found to be positively related to location, trustworthiness, promotional offers, quality, and travel convenience. Unorganized retailers are lacking in services related to cleanliness, offers, quality and helpful trust worthy sales people. Hino (2010) observed in his study that emergence and expansion of organized retail stores gradually reduce the market share of the traditional formats. Factors that helped organized retailers in attracting consumers over the traditional stores are the 'consumers economic ability' and the 'format output'. The consumer has multiple options to choose- ranging from the shopkeeper to the most sophisticated supermarkets, departmental stores, plazas and malls which provide the latest and better quality products and it made India the top spot among the favored retail destination as observed by Gupta (2004), Jasola (2007) and India Retail Report (2009).

Jayakumar and Samad, 2011 mention in their study that there is no firm data for the total value of India's annual food \& beverage expenditure; however there are various calculations and estimates on the bases of Indian government estimates of average urban and rural household expenditure on food and beverages it is comely believed that less than $1 \%$ of food and beverage retail sales take place through the organized retail sector, through this share is estimated to grow rapidly. Prem et. al (2005) made a critical evaluation of different models of service quality and identifies issues for future research based on critical analysis of the literature. The article examines 19 different service quality models reported in literature. A critical examination of different models of service quality is to derive link between them and highlight the area for further research. The review of different service quality model discover that the service quality outcome and measurement depends on type of service setting, time, need and situation as well as customers expectations.

\section{Research Methodology}

\subsection{Research problem}

As organized retail sector is one of the growing sector in India and organized food retail is most attractive category out of all categories of organized retailers. A part from growth organized food retailers face many challenges is perish ability of food, wastage of products, dealing with number of small suppliers, inflated food prices, changing customer habit to purchase food and grocery from traditional retail to organized retail etc. Apart from these maintaining consistency in services along with changing expectations of customers is require a depth research related to identifying essential quality parameters from customers point of view. Although India is a most attractive destination for investment in organized retail sector due to certain reasons growth of 
organized retail sector not reaches the expected figure. So it is very important to know for organized retailers as well as for customers that at which point their expectations are differ.

According to research problem addressed in this study is as follows:

"Which are the important quality parameters at time of purchase for food and grocery items from organized retail malls?"

\subsection{Objective of the research}

1. To identify important parameters of quality provided by organized food and grocery retails to their customers in Rajkot city.

2. To identify factors which are important for customers' satisfaction in organized food and grocery retail stores.

3. To identify areas in which customers are dissatisfied about services of organized food and grocery retailers.

4. To identify level of overall service quality provided to organized food retail customers.

\subsection{Scope of the study}

Broadly the scope of the study is to identify essential quality parameters for organized food retailers considering the customers view point. Identify the key area of services on the basis of which organized food retailers can provide better customer satisfaction and retain them for a longer period of time.

There is a significant relationship between quality of services offered and customer satisfaction intertwined in theory, practice, literature etc.

H1: There is a significant relationship between product variety offers to customers and customer satisfaction in OFR.

$\mathrm{H} 2$ : There is a significant relationship between hygiene and cleanliness at store and customer satisfaction in OFR.

H3: There is a significant relationship between offers and discounts offered by store and customer satisfaction in OFR.

H4: There is a significant relationship between method of bill payment and customer satisfaction in OFR.

H5 : There is a significant relationship between product quality and customer satisfaction in OFR.

\subsection{Significance of the study}

India is a most attractive destination for organized retail business due to still unexploited and under penetrated market. A part from growth organized retailers faces many issues related to developing new customers and retaining them, poor supply chain, increasing investment cost in real estate, increasing food prices due to inflation, economic recession and many more.

To cope up with these situation retailers need to take multiple initiatives to fix retail basics and ensure growth to meet the targets. According to recent survey made by KPMG retailers should identify true metric for success which is not in expanding number of stores but increasing same store sales through understanding consumer requirements and identifying right quality parameters of services they provide. Any retailer who get fail to identify these parameters of service quality expected by consumers may not find growth opportunities for longer period of time.

\subsection{Methodology}

The empirical investigation was done of 100 respondents to measure the essential parameters of service quality provided by organized food retailers. Questionnaires were distributed utilizing a convenient sampling to customers visited at organize food retail stores. Food retail stores include Big Bazaar, Reliance Fresh and D Mart. The study was conducted in Rajkot city. 12 statements were included in a questionnaire to know the customers opinion about different parameters of service quality. The satisfaction level was used as a dependent variable and regressed on the remaining 12 independent variable labeled as $\mathrm{X} 1, \mathrm{X} 2, \ldots . \mathrm{X} 12$. The essential quality parameters were examined using factor analysis based on the 12 individual statements of the questionnaire. The Kaiser-Meyer-Olkin test and the Bartlett's test of sphericity is conducted to see whether the data is conducive to conduct factor analysis. Both the test shows significant result.

TABLE : 1 KMO and Bartlett's Test

\begin{tabular}{|c|c|}
\hline $\begin{array}{l}\text { Kaiser-Meyer-Olkin Measure of Sampling Adequacy. } \\
\text { Bartlett's Test of Sphericity } \\
\qquad \begin{array}{l}\text { Approx. Chi-Square } \\
\text { df } \\
\text { Sig. }\end{array}\end{array}$ & $\begin{array}{l}.643 \\
239.566 \\
66 \\
.000\end{array}$ \\
\hline
\end{tabular}


Using Principal Component Analysis extraction method with Varimax rotation, it is observed in below table that on table : 2

TABLE : 2 Communalities

\begin{tabular}{|l|l|l|}
\hline & Initial & Extraction \\
\hline X1 : Super markets are not conveniently located. & 1.000 & .715 \\
X2 : There is a greater hygiene and neatness at super markets. & 1.000 & .644 \\
X3: Supermarkets provide attractive discounts and schemes. & 1.000 & .625 \\
X4: More fresh food and better quality grocery products at super markets. & 1.000 & .612 \\
X5 : supermarkets provide more shopping convenience compare to local & 1.000 & .791 \\
kirana stores. & 1.000 & .611 \\
X6 : Supermarkets offers larger variety of products under one roof. & 1.000 & .426 \\
X7 : Supermarkets offers convenience in mode of payment. & 1.000 & .622 \\
X8 : Long queues for Billing in super market create problem. & 1.000 & .572 \\
X9 : Lack of Credit facility lead toward unorganized retail . & 1.000 & .524 \\
X10 : Super markets are not good at after sales services. & 1.000 & .480 \\
X11: They provide lesser personal attendance to customers. & 1.000 & .663 \\
X12: Services are not provided consistently in super markets. & \\
\hline
\end{tabular}

X12: Services are not provided consistently in super markets.

TABLE : 3 Total Variance Explained

\begin{tabular}{|c|c|c|c|c|c|c|c|c|c|}
\hline \multirow[t]{2}{*}{$\begin{array}{l}\text { Compon } \\
\text { ent }\end{array}$} & \multicolumn{3}{|c|}{ Initial Eigenvalues } & \multicolumn{3}{|c|}{$\begin{array}{l}\text { Extraction Sums of Squared } \\
\text { Loadings }\end{array}$} & \multicolumn{3}{|c|}{$\begin{array}{l}\text { Rotation Sums of Squared } \\
\text { Loadings }\end{array}$} \\
\hline & Total & $\begin{array}{l}\% \\
\text { Variance }\end{array}$ & $\begin{array}{l}\text { of } \begin{array}{l}\text { Cumulative } \\
\%\end{array} \\
\end{array}$ & Total & $\begin{array}{l}\% \\
\text { Variance }\end{array}$ & \begin{tabular}{l|l} 
of & $\begin{array}{l}\text { Cumulat } \\
\text { ive } \%\end{array}$ \\
\end{tabular} & Total & $\begin{array}{l}\% \\
\text { Variance }\end{array}$ & $\begin{array}{l}\text { Cumulative } \\
\%\end{array}$ \\
\hline 1 & 2.645 & 22.042 & 22.042 & 2.645 & 22.042 & 22.042 & 2.124 & 17.699 & 17.699 \\
\hline 2 & 2.155 & 17.962 & 40.004 & 2.155 & 17.962 & 40.004 & 1.853 & 15.441 & 33.140 \\
\hline 3 & 1.340 & 11.171 & 51.174 & 1.340 & 11.171 & 51.174 & 1.694 & 14.119 & 47.258 \\
\hline 4 & 1.144 & 9.537 & 60.712 & 1.144 & 9.537 & 60.712 & 1.614 & 13.454 & 60.712 \\
\hline 5 & .954 & 7.953 & 68.665 & & & & & & \\
\hline 6 & .785 & 6.539 & 75.204 & & & & & & \\
\hline 7 & .651 & 5.428 & 80.632 & & & & & & \\
\hline 8 & .613 & 5.112 & 85.743 & & & & & & \\
\hline 9 & .549 & 4.572 & 90.315 & & & & & & \\
\hline 10 & .488 & 4.070 & 94.385 & & & & & & \\
\hline 11 & .375 & 3.128 & 97.513 & & & & & & \\
\hline 12 & .298 & 2.487 & 100.000 & & & & & & \\
\hline
\end{tabular}

Extraction Method: Principal Component Analysis.

TABLE :4 Component Matrix

\begin{tabular}{|c|c|c|c|c|}
\hline & \multicolumn{4}{|c|}{ Component } \\
\hline & 1 & 2 & 3 & 4 \\
\hline $\mathrm{X} 1$ : Super markets are not conveniently located & -.028 & .762 & -.308 & 199 \\
\hline $\mathrm{X} 2$ : There is a greater hygiene and neatness at super markets & .606 & 106 & 416 & 304 \\
\hline X3: Supermarkets provide attractive discounts and schemes & .524 & 307 & -.486 & 141 \\
\hline $\begin{array}{c}\mathrm{X} 4: \text { More fresh food and better quality grocery products at super } \\
\text { markets }\end{array}$ & .599 & .108 & .417 & 260 \\
\hline $\begin{array}{c}\mathrm{X} 5 \text { : Supermarkets provide more shopping convenience compare to local } \\
\text { kirana stores }\end{array}$ & .240 & .749 & -.410 & .063 \\
\hline $\mathrm{X} 6$ : Supermarkets offers larger variety of products under one roof & .749 & .027 & 214 & .058 \\
\hline $\mathrm{X} 7$ : Supermarkets offers convenience in mode of payment & 629 & $\mid-163$ & .033 & .056 \\
\hline $\mathrm{X} 8$ : Long queues for Billing in super market create problem & .590 & -130 & -.112 & 494 \\
\hline $\mathrm{X} 9$ : Lack of Credit facility lead toward unorganized retail & .361 & -201 & -.272 & 571 \\
\hline $\mathrm{X} 10$ : Super markets are not good at after sales services & -266 & .524 & 357 & 225 \\
\hline X11: They provide lesser personal attendance to customers & -.267 & 470 & 390 & 191 \\
\hline $\mathrm{X} 12$ - Services are not provided consistently in super markets. & .087 & 562 & .286 & 507 \\
\hline
\end{tabular}


Measuring essential quality parameters for organized food retailers - A survey in Rajkot city

\begin{tabular}{|c|c|c|c|c|}
\hline \multicolumn{5}{|c|}{$\begin{array}{l}\text { TABLE : } 5 \text { Rotated Component Matrix }{ }^{\mathrm{a}} \\
\text { Component }\end{array}$} \\
\hline & 1 & 2 & 3 & 4 \\
\hline $\mathrm{X} 1$ : Super markets are not conveniently located & -.065 & 776 & .236 & -.232 \\
\hline $\mathrm{X} 2$ : There is a greater hygiene and neatness at super markets & 800 & 041 & .021 & -050 \\
\hline X3: Supermarkets provide attractive discounts and schemes & 225 & 676 & -243 & 240 \\
\hline $\begin{array}{l}\text { 4: More fresh food and better quality grocery products at super } \\
\text { markets }\end{array}$ & 780 & .032 & .045 & -.020 \\
\hline $\begin{array}{l}\text { X5: Supermarkets provide more shopping convenience compare to local } \\
\text { cirana stores. }\end{array}$ & 046 & .868 & 183 & .046 \\
\hline $\mathrm{X} 6$ : Supermarkets offers larger variety of products under one roof & 720 & 091 & -.050 & 288 \\
\hline $\mathrm{X} 7$ : Supermarkets offers convenience in mode of payment & 480 & 007 & -192 & 398 \\
\hline $\mathrm{X} 8$ : Long queues for Billing in super market create problem & 232 & .022 & -.027 & 753 \\
\hline X9: Lack of Credit facility lead toward unorganized retail & -.062 & -.008 & -.075 & $750^{\circ}$ \\
\hline $\mathrm{X} 10$ : Super markets are not good at after sales services & -.063 & 058 & 700 & -162 \\
\hline X11: They provide lesser personal attendance to customers & -.039 & 005 & 666 & -187 \\
\hline $\mathrm{X} 12$ - Services are not provided consistently in super markets. & 1.085 & 161 & 751 & 257 \\
\hline
\end{tabular}

Extraction Method: Principal Component Analysis.

Rotation Method: Yarimax with Kaiser Normalization

a. Rotation converged in 5 iterations.

The result indicates that four factors resulting from analysis explaining a total of 60.712 per cent pf the variations in the entire data set (table: 1). The percentage of variation explained by the first, second, third and fourth factors are $17.699,15.441,14.119 \& 13.454$ percent respectively after varimax rotation is performed. Rotated component matrix was used for factor loading for naming the factors (Table: 5) in this way four factors were identified. Factor 1 PRODUCT QUALITY will consist of variables X2 (There is a greater hygiene and neatness at super markets), X4 (More fresh food and better quality grocery products at super markets) and X6 (Supermarkets offers larger variety of products under one roof). Factor 2 PURCHASE CONVINIENCE will consist of variables X1 (Super markets are not conveniently located), X3 (Supermarkets provide attractive discounts and schemes) and X5 (supermarkets provides more shopping convenience compare to local kirana stores). Factor 3 STORE SERVICE will consist of variables X10 (Super markets are not good at after sales services), X11 (They provide lesser personal attendance to customers) and X12 (Services are not provided consistently in super markets.). Factor 4 PAYMENT CONVENIENCE will consist of variable X8(Long queues for Billing in super market create problem) and X9(Lack of Credit facility lead toward unorganized retail). It would be interesting to know that the factor loading for factor 3 with variable $X 7$ is negative. Since the variable X7 means that super markets offers convenience in mode of payment, a negative of this statement would be that customers think that supermarkets not offers convenience in mode of payment and this is the reason why the factor loading came out to be negative.

\section{Conclusion}

The study provides some important factors which are important for customer's point of view in evaluating service quality provided by organized food retail stores of Rajkot city. There is a strong indication that customers change the way they evaluate a firm's service as increase in customer expectations and more availability of different service providers. It become essential for service providers to acquire understanding of overall service quality provided by them as well as which factors consider more importantly by customers in evaluating services.

\section{References}

[1] Hardeep Chahal and Neetu Kumari, Service quality, customer satisfaction and customer loyalty in health care sector, The Indian journal of commerce, 62 (2), 2009, 71-84.

[2] Kathryn Bishop Gagliano and Jan Hathcote, Customer expectations and perceptions of service quality in retail apparel speciality stores, Journal of service marketing, 8(1) 1994, 60-69.

[3] G. S. Sureshchandar, Chandrasekharan \& R. N. Anantharaman, Deterninants of customer perceived service quality. Journal of services marketing. 16(1), 2002, 9-34.

[4] Jaykumar and Samad, Identifying important service quality parameters for major Indian food retailers, African journal of marketing management, 4(1), 2012, 30-42.

[5] Joseph, Soundararajan, Gupta, Sahu, Impact of organized retailing on the unorganized sector, Indian council for research on international economic relations. 2008, WP. 222 
[6] Sinha, Mathew \& Kansal, 2003-05. Format choice of food and grocery retailer. IIMA research and publication. WP No. 2005-0704.

[7] Top trends in Indian retail sector. Techno park retail outlook, Oct.' 2007, Vol-1.

[8] Retail global expansion: A portfolio of opportunities, A.T.Kearney global retail development index, 2011.

[9] Deepak Chawla \& Neena Sondhi, Research methodology concepts and case, Vikas publishing house Pvt Ltd., 2011. 